\title{
Flow Assessment of Self-Compacted Concrete incorporating Fly Ash
}

\author{
Muneeb Ayoub Memon \\ Department of Civil Engineering \\ Quaid-e-Awam University of \\ Engineering, Science \& Technology \\ Pakistan \\ engr.muneebmemon@gmail.com
}

\author{
Noor Ahmed Memon \\ Department of Civil Engineering \\ Quaid-e-Awam University of \\ Engineering, Science \& Technology \\ Pakistan \\ nahmedmemon@gmail.com
}

\author{
Aftab Hameed Memon \\ Department of Civil Engineering \\ Quaid-e-Awam University of \\ Engineering Science \& Technology \\ Pakistan \\ aftabm78@hotmail.com
}

\author{
Riaz Bhanbhro \\ Department of Civil Engineering \\ Quaid-e-Awam University of Engineering, Science \& \\ Technology \\ Pakistan \\ riaz@quest.edu.pk
}

\author{
Mujahid Hussain Lashari \\ Department of Civil Engineering \\ Quaid-e-Awam University of Engineering, Science \& \\ Technology \\ Pakistan \\ emhlashari@gmail.com
}

\begin{abstract}
Flow ability is one of the prime characteristics of good concrete and plays a key role in Self Compacting Concrete (SCC). This study assesses flow ability of SCC in which cement content was reduced and replaced by fly ash. Several mixes were prepared by using $5 \%$ to $30 \%$ fly ash. From the experimental work it was realized that by adjusting a suitable percentage of Super Plasticizer (SP), fly ash dosage can be increased with satisfactory fresh properties of concrete in accordance with the guidelines of EFNARC. At $T_{50 \mathrm{~cm}}$ time the optimum amount of SP was $2 \%$. It was noted that with increase in dosage of fly ash the slump flow increased but $T_{50 \mathrm{~cm}}$ and $V$-funnel time were reduced. J-Ring height value varied from 9 to 10 for all the mixes.
\end{abstract} flow

Keywords-self compacting concrete; flow ability; fly ash; slump

\section{INTRODUCTION}

Self Compacting Concrete (SCC) is popular because it is a workable concrete with a satisfactory level of strength. It is very useful for narrow sections with ignorable level of segregation and higher flexibility $[1,2]$. SCC is also proved to be very useful when reinforcement is very congested. SCC offers ease in pouring compared to ordinary concrete and hence has more commercial benefits [2,3]. Although compared to ordinary concrete, SCC is a little more expensive but this can be compensated by replacing cement content with supplementary cementitious materials [4-6]. The incorporation of cementitious materials such as metakaolin ash in SCC not only enhances its properties at fresh and hardened state but also decreases the cost of materials and the amount of produced $\mathrm{CO}_{2}$ [7-12]. Fly Ash (FA) is one of the commonly used cementitious materials used in producing economical and ecofriendly SCC with a satisfactory level of performance [13, 14]. It is also useful in reducing the necessary quantity of Super Plastisizer (SP) for maintaining the required slump flow [15].
The overall performance of SCC can be further improved by using mixtures of different fillers of FA with lime stone and/or any other natural pozzolanic materials $[16,17]$. The benefits of incorporating cement replacement materials depend on their type, dosage, and physical and chemical composition [18]. The use of FA is very helpful in decreasing the requirement of water in the manufacturing of SCC with a liquefied consistency [19]. On the other hand, when Palm Oil Fuel Ash (POFA) was used instead of Ordinary Portland Concrete (OPC), it increased its initial and final setting time but reduced passing ability. This has gained high importance in concrete technology [21-25]. POFA and FA have been used in [26] in SCC individually and combined. It was observed that FA shows better performance than POFA in all measured characteristics of SCC mixes. Furthermore, it was also reported that the use of higher quantity of POFA and FA has a momentous possibility for medium strength concrete. Authors in [25] used blends of FA, GGBS and SF for assessing SCC and found that FA is the major material in decreasing the compressive strength of the concrete, whereas authors in [21] used FA, marble powder (M) and limestone filler (LF) in SCC and found that the compressive strength of SCC with binary concrete samples was better than of concrete with FS at an early age but there was no difference at a later age.

\section{EXPERIMENTAL PROCEDURE}

Figure 1 shows the flowchart of the current research, which starts from literature review, goes to the selection of materials, physical and chemical analysis of materials, and mix design by ENNARC [1], and evaluates the fresh properties of concrete reaching the final conclusions. OPC conforming ASTMC150M-18 and class F Fly Ash (FLA) as per ASTM C 618-17 were used. 


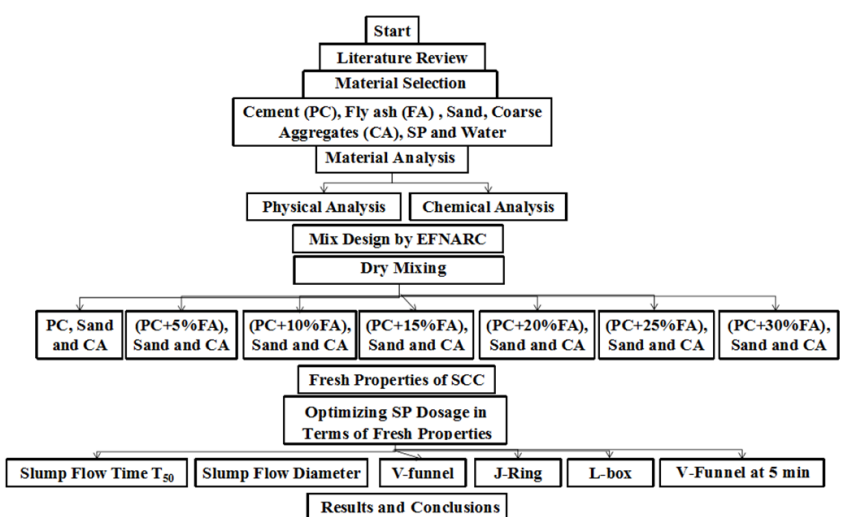

Fig. 1. Flowchart showing the work methodology

Figures 2-3 demonstrate the chemical compositions of OPC and FLA respectively. Table I shows the values of physical and chemical analysis. Fine Aggregates (FA) passed from \#4 sieves and Coarse Aggregates (CA) with $13 \mathrm{~mm}$ maximum size were used throughout the study. The gradation of aggregates presented in Table II. A poly-carboxylate based SP was used to maintain the required workability. In order to investigate the flow characteristics of SCC, seven different mixtures were produced in total with varying percentage replacement of cement by FLA with one being the control mixture as shown in Table III. The fresh properties checked were filling ability, passing ability and segregation resistance. The filling ability was evaluated by slump flow time $T_{50 \text { sec }}$, slump flow diameter, and V-funnel time. The passing ability was measured with $\mathrm{J}$ ring height, and L-box height ratio. V-funnel time at 5 minutes was recorded as a segregation resistance test.

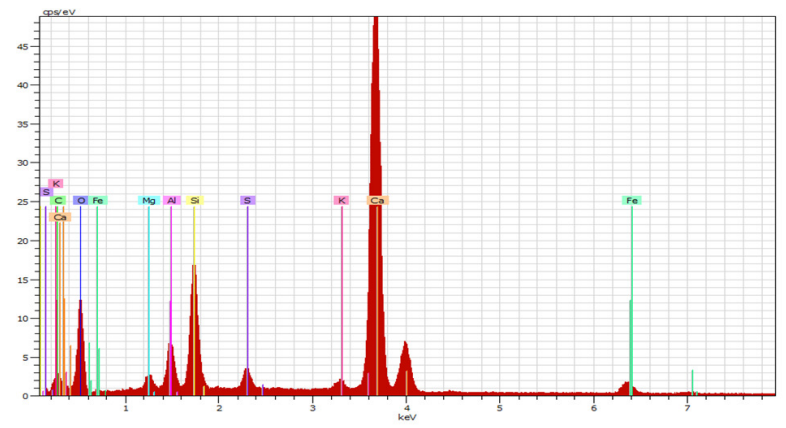

Fig. 2. Chemical composition of OPC

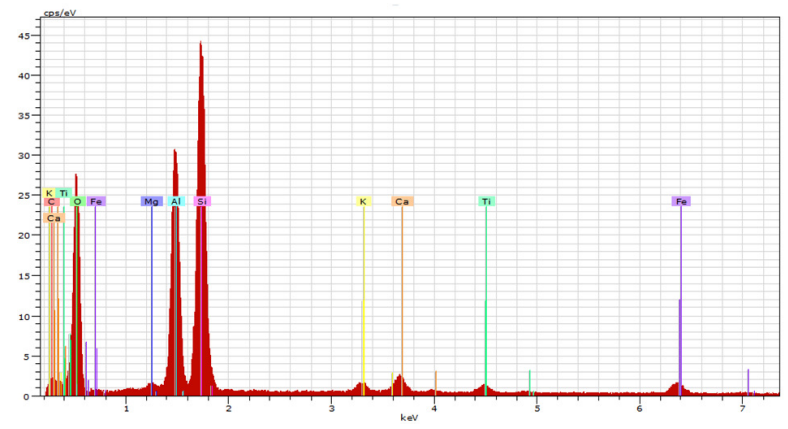

Fig. 3. Chemical composition of FLA
TABLE I. MATERIALS REQUIRED FOR $1 \mathrm{~m}^{3}$ OF SCC

\begin{tabular}{|c|c|c|c|c|c|c|c|c|c|}
\hline $\begin{array}{c}\text { Mix } \\
\text { ID }\end{array}$ & $\begin{array}{c}\text { Mix } \\
\mathbf{d e s c r i p t i o n}\end{array}$ & $\begin{array}{c}\text { OPC } \\
\mathbf{k g} / \mathbf{m}^{3}\end{array}$ & $\begin{array}{c}\text { FLA } \\
\mathbf{k g} / \mathbf{m}^{\mathbf{3}}\end{array}$ & $\begin{array}{c}\text { Binder } \\
\mathbf{k g} / \mathbf{m}^{\mathbf{3}}\end{array}$ & $\begin{array}{c}\mathbf{F A} \\
\mathbf{k g} / \mathbf{m}^{3}\end{array}$ & $\begin{array}{c}\mathbf{C A} \\
\mathbf{k g} / \mathbf{m}^{3}\end{array}$ & $\mathbf{W} / \mathbf{B}$ & $\begin{array}{c}\text { Water } \\
\mathbf{k g} / \mathbf{m}^{3}\end{array}$ & $\begin{array}{c}\mathbf{S P} \\
\mathbf{k g} / \mathbf{m}^{3}\end{array}$ \\
\hline M1 & PC & 550 & 0 & 550 & 870 & 880 & 0.34 & 187 & 11 \\
\hline M2 & $5 \%$ FLA & 522.5 & 27.5 & 550 & 870 & 880 & 0.34 & 187 & 11 \\
\hline M3 & $10 \%$ FLA & 495 & 55 & 550 & 870 & 880 & 0.34 & 187 & 11 \\
\hline M4 & $15 \%$ FLA & 467.5 & 82.5 & 550 & 870 & 880 & 0.34 & 187 & 11 \\
\hline M5 & $20 \%$ FLA & 440 & 110 & 550 & 870 & 880 & 0.34 & 187 & 11 \\
\hline M6 & $25 \%$ FLA & 412.5 & 137.5 & 550 & 870 & 880 & 0.34 & 187 & 8.25 \\
\hline M7 & $30 \%$ FLA & 385 & 165 & 550 & 870 & 880 & 0.34 & 187 & 5.5 \\
\hline
\end{tabular}

TABLE II. OPC AND FLA PHYSICAL AND CHEMICAL PROPERTIES

\begin{tabular}{|c|c|c|}
\hline & OPC (\%) & FLA (\%) \\
\hline $\mathrm{SiO}_{2}$ & 15.1 & 47.98 \\
\hline $\mathrm{Al}_{2} \mathrm{O}_{3}$ & 6.27 & 30.4 \\
\hline $\mathrm{MgO}$ & 2.089 & 0.945 \\
\hline $\mathrm{CaO}$ & 59.35 & 2.994 \\
\hline $\mathrm{Fe}_{2} \mathrm{O}_{3}$ & 4.003 & 4.07 \\
\hline $\mathrm{K}_{2} \mathrm{O}$ & 1.421 & 1.84 \\
\hline $\mathrm{SO}_{3}$ & 3.495 & - \\
\hline $\mathrm{TiO}_{2}$ & - & 2.185 \\
\hline Loss of ignition & 2.64 & 1.32 \\
\hline Specific gravity & 3.25 & 2.13 \\
\hline
\end{tabular}

TABLE III. SIEVE ANALYSIS OF FINE AND COARSE AGGREGATES

\begin{tabular}{|c|c|c|}
\hline \multirow{2}{*}{ Sieve size (mm) } & Fine aggregates & Coarse aggregates \\
\cline { 2 - 3 } & Passing (\%) & Passing (\%) \\
\hline 13.2 & 100 & 95.43 \\
\hline 9.5 & 100 & 46.1 \\
\hline 4.75 & 99.8 & 0.35 \\
\hline 2.36 & 83.96 & 0 \\
\hline 1.18 & 66.42 & 0 \\
\hline 0.6 & 54.1 & 0 \\
\hline 0.3 & 38.1 & 0 \\
\hline 1.15 & 9.1 & 0 \\
\hline pan & 0 & 0 \\
\hline
\end{tabular}

\section{RESULTS AND DISCUSSION}

\section{A. SP Dosage Optimization}

It is well recognized that SP is added in SCC to achieve the required workability. Therefore, it was necessary to acquire the optimized dosage of SP in the selected mixes. For this purpose, slump flow time $\mathrm{T}_{50 \mathrm{~cm}}$ tests were conducted to get the optimized dosage of SP from the trial batches of each mix. $\mathrm{T}_{50 \mathrm{~cm}}$ time should be within the range of $2-6 \mathrm{~s}$. The workability of SCC increases with increase in the dosage of SP as can be seen in Table IV. Table V shows the observed results of fresh characteristics during various lab tests.

TABLE IV. VARIATION OF SLUMP FLOW TIME WITH SP DOSAGE

\begin{tabular}{|c|c|c|c|c|c|}
\hline SP dosage & $\mathbf{1}$ & $\mathbf{1 . 5}$ & $\mathbf{2}$ & $\mathbf{2 . 5}$ & $\mathbf{3}$ \\
\hline Mixes & \multicolumn{5}{|c|}{$\mathbf{T}_{\mathbf{5 0 c m}}$ slump flow time (sec) } \\
\hline Control & 12 & 9.3 & 4.6 & -- & -- \\
\hline $\mathbf{5 \%}$ & -- & -- & 4.4 & 3.9 & 2.6 \\
\hline $\mathbf{1 0 \%}$ & -- & -- & 4.3 & 3.3 & 3 \\
\hline $\mathbf{1 5 \%}$ & -- & -- & 4.2 & 4 & 2.3 \\
\hline $\mathbf{2 0 \%}$ & -- & -- & 4.1 & 3.1 & 2 \\
\hline $\mathbf{2 5 \%}$ & -- & 4.2 & 3.2 & 2.5 & 2.1 \\
\hline $\mathbf{3 0 \%}$ & 3.9 & 3.6 & 3 & 2.1 & -- \\
\hline
\end{tabular}




\section{B. Filling Ability}

The filling ability was assessed through $\left(\mathrm{T}_{50 \mathrm{~cm}}\right)$, slump flow diameter and V-funnel tests. Figures 4-6 show the variation of slump flow time, slump flow diameter, and V-funnel flow time respectively, for the tested mixes including control. It can be seen from these figures that $\mathrm{T}_{50 \mathrm{~cm}}$ and $\mathrm{V}$-funnel time decrease with increasing in fly ash percentage. Likewise, slump flow diameter is slightly increasing for increased replacement levels of fly ash due to the viscosity modifying properties of fly ash. The filling ability values of all mixes with the optimised dosages of SP were within the required range [1].

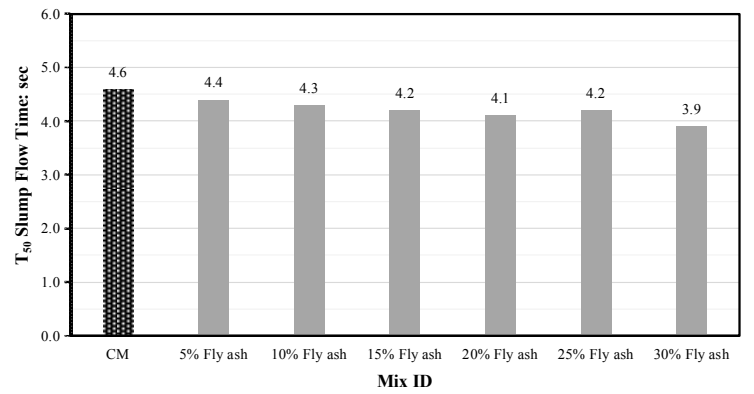

Fig. 4. Variation in $\mathrm{T}_{50 \mathrm{~cm}}$ with fly ash dosage

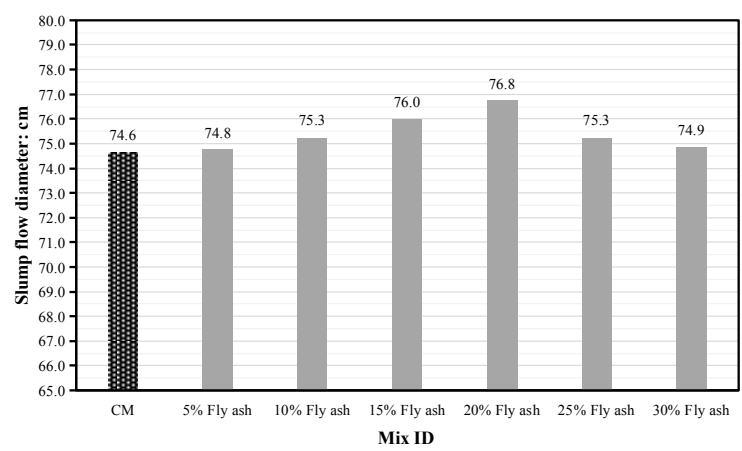

Fig. 5. Variation in slump flow diameter with fly ash dosage

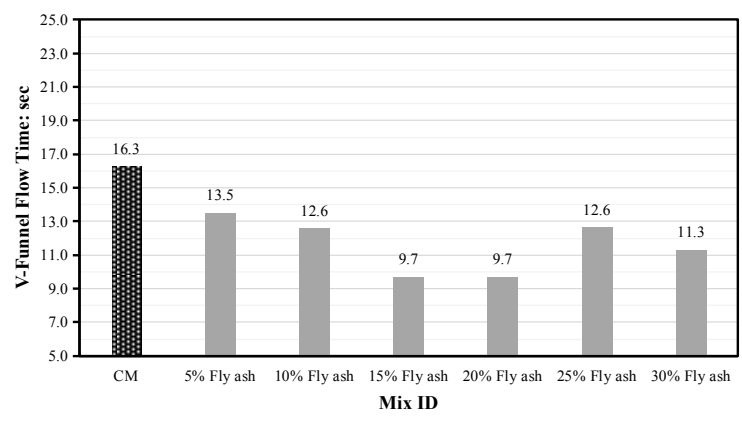

Fig. 6. Variation in V-funnel flow time with fly ash dosage

\section{Passing Ability}

Passing ability is a major characteristic of SCC in maintaining concrete flow. When structural components are very narrow or highly reinforced with small spaces between them, passing ability is more important than the uniformity of concrete. At laboratory level, this can be performed through the
J-Ring and L-box tests. The height of J-Ring and L-box height ratio $(\mathrm{H} 2 / \mathrm{H} 1)$ are given in Table $\mathrm{V}$ which depicts the passing ability of prepared mixes confirming the desired level as suggested by EFNARC.

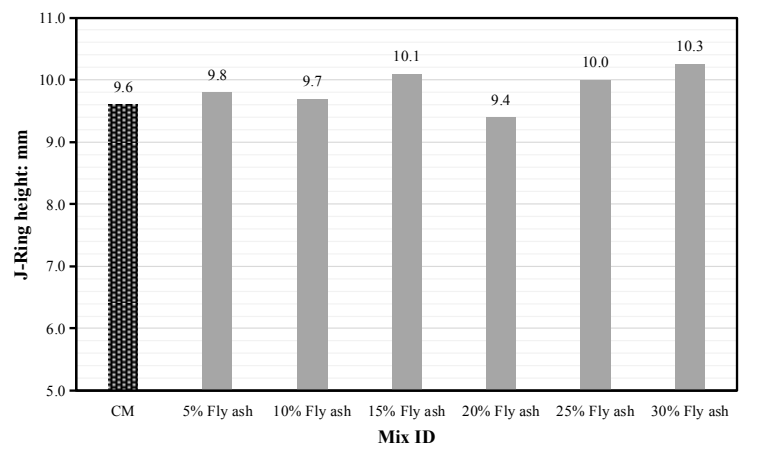

Fig. 7. Variations in J-Ring height with fly ash dosage

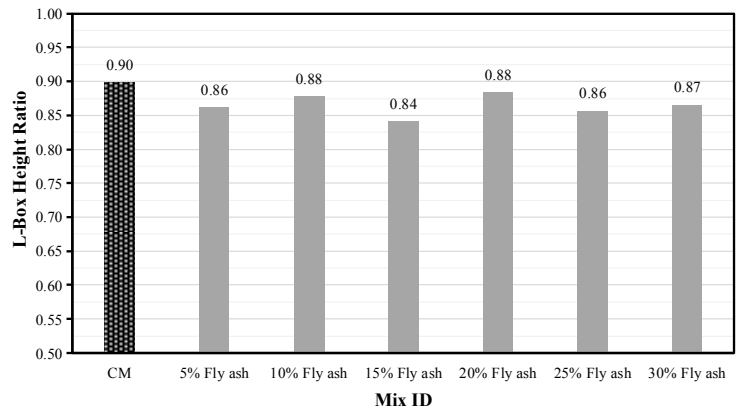

Fig. 8. Variations in L-Box height ratio with fly ash dosage

\section{Segregation Resistance}

The consistency of the mixes was inspected through the VFunnel test at $5 \mathrm{~min}$. It is observed from Figure 9 that for all the mixes the $\mathrm{V}$-funnel flow time was in the required range $(8-25 \mathrm{~s})$ according to the EFNARC guidelines.

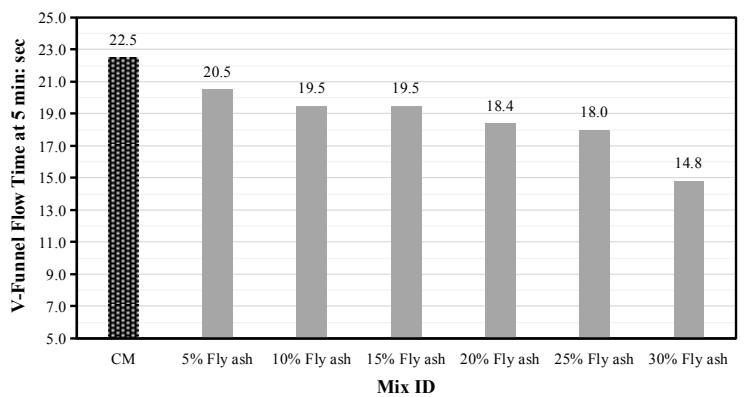

Fig. 9. Variation in V-Funnel flow time at (5min) with fly ash dosage

\section{CONCLUSIONS}

The fresh properties assessed by the workability tests of SCC depend upon the dosage of fly ash in the mix which can be adjusted by a suitable percentage of $S P$. $T_{50 \mathrm{~cm}}$ is the key test for the fresh properties of SCC, while $\mathrm{T}_{50 \mathrm{~cm}}$ time between 4 and $5 \mathrm{~s}$ is considered optimum. On the basis of $\mathrm{T}_{50 \mathrm{~cm}}$ time, the optimized dosage of SP for mixes are (CM 2\%), (5FA $2 \%)$, 
(10FA 2\%), (15FA 2\%), (20FA 2\%), (25FA 1.5\%) and (30FA $1 \%$ ). Slump flow diameter increases and $\mathrm{T}_{50 \mathrm{~cm}}$ and $\mathrm{V}$-funnel time decrease with increase in the percentage of fly ash. J-ring height for all the mixes ranged from 9 to $10 \mathrm{~mm}$. The values of
L-box height ratio for all mixes are between 0.8 and 1.0. It was observed that filling ability, passing ability and segregation resistance for all the mixes with the optimised SP dosage were within the required range as per EFNARC.

TABLE V. SCC FRESH PROPERTIES

\begin{tabular}{|c|c|c|c|c|c|c|}
\hline & \multicolumn{3}{|c|}{ Filling ability } & \multicolumn{2}{|c|}{ Passing ability } & \multirow{2}{*}{\begin{tabular}{|c|} 
Segregation resistance \\
$\begin{array}{c}\text { V-funnel time at } 5 \mathrm{~min}(\mathrm{~s}) \\
\text { limits }[8-25] \mathrm{s}\end{array}$ \\
\end{tabular}} \\
\hline Mix & \begin{tabular}{|c|}
$\begin{array}{c}\text { Slump flow time (s) } \\
\text { limits }[2-5] ~ s e c\end{array}$
\end{tabular} & $\begin{array}{c}\text { Slump flow diameter }(\mathrm{cm}) \\
\text { limits }[65-80] \mathrm{cm}\end{array}$ & $\begin{array}{l}\text { V-funnel time (s) } \\
\text { limits }[6-25] \mathrm{s}\end{array}$ & $\begin{array}{l}\text { J-ing height }(\mathrm{mm}) \\
\text { limits }[0-10] \mathrm{mm}\end{array}$ & $\begin{array}{l}\text { L-box height ra io } \\
\text { limits [0.8-1 }\end{array}$ & \\
\hline PC & 4.6 & 74.6 & 16.3 & 9.6 & 0.90 & 22.5 \\
\hline $5 \%$ & 4.4 & 74.8 & 13.5 & 9.8 & 0.86 & 20.5 \\
\hline $10 \%$ & 4.3 & 75.3 & 12.6 & 9.7 & 0.88 & 19.5 \\
\hline $15 \%$ & 4.2 & 76.0 & 9.7 & 10.1 & 0.84 & 19.5 \\
\hline $20 \%$ & 4.1 & 76.8 & 9.7 & 9.40 & 0.88 & 18.4 \\
\hline $25 \%$ & 4.2 & 75.3 & 12.6 & 10.0 & 0.86 & 18.0 \\
\hline $30 \%$ & 3.9 & 74.9 & 11.3 & 10.3 & 0.87 & 14.8 \\
\hline
\end{tabular}

\section{ACKNOWLEDGMENT}

The authors are grateful to the Quaid-e-Awam University of Engineering, Science and Technology, Nawabshah for providing the research facilities.

\section{REFERENCES}

[1] Specification and guidelines for self-compacting concrete, in European Federation of Producers and Applicators of Specialist Products for Structures (EFNARC), 2005

[2] ASTM C494/C494M-15 (2003): Chemical admixtures for concrete, ASTM C494/C494M-15, 2003

[3] H. A. Mohamed, "Effect of fly ash and silica fume on compressive strength of self compacting concrete under different curing conditions", Ain Shams Engineering Journal, Vol. 2, No. 2, pp. 79-86, 2011

[4] G. S. Rampradheep, M. Sivaraja, "Experimental investigation on selfcompacting self curing concrete incorporated with the light weight aggregates", Brazilian Archives of Biology and Technology, Vol. 59, pp. $1-11,2016$

[5] N. A. Memon, M. A. Memon, N. A. Lakho, F. A. Memon, M. A. Keerio, A. N. Memon, "A Review on Self Compacting Concrete with Cementitious Materials and Fibers", Vol. 8, No. 3, pp. 2969-2974, 2018

[6] N. Bheel, A. W. Abro, I. A. Shar, A .A. Dayo, S. Shaikh, Z. H. Shaikh, "Use of Rice Husk Ash as Cementitious Material in Concrete", Vol. 9, No. 3, pp. 4209-4212, 2019

[7] O. Almuwbber, R. Haldenwang, W. Mbasha, I. Masalova, "The influence of variation in cement characteristics on workability and strength of SCC with fly ash and slag additions", Construction and Building Materials, Vol. 160,pp. 258-267, 2018

[8] N. Bouzoubaa, M. Lachemi, "Self-compacting concrete incorporating high volumes of class F fly ash: Preliminary results", Cement and Concrete Research, Vol. 31, No. 3, pp. 413-420, 2001

[9] I. Mehdipour, M. S. Razzaghi, K. Amini, M. Shekarchi, "Effect of mineral admixtures on fluidity and stability of self-consolidating mortar subjected to prolonged mixing time", Construction and Building Materials, Vol. 40, pp. 1029-1037, 2013

[10] A. Mohan, K. M. Mini, "Strength and durability studies of SCC incorporating silica fume and ultra fine GGBS", Construction and Building Materials. Vol. 171, pp. 919-928, 2018

[11] O. Almuwbber, R. Haldenwang, W. Mbasha, I. Masalova, "The influence of variation in cement characteristics on workability and strength of SCC with fly ash and slag additions", Construction and Building Materials, Vol. 160,pp. 258-267, 2018

[12] E. Vejmelkova, M. Keppert, S. Grzeszczyk, B. Skalinski, R. Cerny, "Properties of self-compacting concrete mixtures containing metakaolin and blast furnace slag”, Construction and Building Materials, Vol. 25, No. 3, pp. 1325-1331, 2011

[13] A. Oner, S. Akyuz, "An experimental study on optimum usage of GGBS for the compressive strength of concrete", Cement and Concrete
Composites, Vol. 29, No. 6, pp. 505-514, 2007

[14] E. H. Yang, Y. Yang, V. C. Li, "Use of high volumes of fly ash to improve ECC mechanical properties and material greenness", ACI Materials Journal, Vol. 104, No. 6, pp. 620-628, 2007

[15] M. Gesoglu, E. Guneyisi, M. E. Kocabag, V. Bayram, K. Mermerdas, "Fresh and hardened characteristics of self-compacting concrete made with combine use of marble powder, limestone filler and fly ash", Construction and Building Materials, Vol. 37, pp. 160-170, 2012

[16] K. D. Weerdt, K. O. Kjellsen, E. Sellevold, H. Justnes, "Synergy between fly ash limestone powder in ternary cement", Cement and Concrete Composites, Vol. 33, No. 1, pp. 30-38, 2011

[17] S. A. Rizwan, T. A. Bier, "Blends of limestone powder and fly-ash enhance the response of self-compacting mortars", Construction and Building Materials, Vol. 27, No. 1, pp. 398-403, 2012

[18] R. Siddique, M. I. Khan, Supplementary cementing materials, Springer, 2011

[19] B. H. Nagaratnam, M. E. Rahman, A. K. Mirasa, M. A. Mannan, S. O. Lame, "Workability and heat of hydration of self-compacting concrete incorporating agro-industrial waste", Journal of Cleaner Production, Vol. 112, pp. 882-894, 2016

[20] R. S. Ahari, T. K. Erdem, K. Ramyar, "Effect of various supplementary cementitious materials on rheological properties of self-consolidating concrete", Construction and Building Materials, Vol. 75, pp. 89-98, 2015

[21] M. Gesoglu, E. Guneyisi, M.E. Kocabag, V. Bayram, K. Mermerdas, "Fresh and hardened characteristics of self compacting concretes made with combined use of marble powder, limestone filler, and fly ash", Construction and Building Materials, Vol. 37, pp. 160-170, 2012

[22] E. Guneyisi, M. Gesoglu, E. Ozbay, "Strength and drying shrinkage properties of self-compacting concretes incorporating multi-system blended mineral admixtures", Construction and Building Materials, Vol. 24, No. 10, pp. 1878-1887, 2010

[23] E. Guneyisi, M. Gesoglu, E. Ozbay, "Permeation properties of selfconsolidating concretes with mineral admixtures, ACI Materials Journal, Vol. 108, No. 2, pp. 150-158, 2011

[24] M. Ismail, I. O. Hassan, A. S. Abdulrahman, P. Forouzani, A. H. Norizman, T. O. Yusuf, "Effect of micro-structure and mineralogical composition on the water demand and super-plasticiser content of ternary blended self-consolidating paste", Thirteenth East Asia-Pacific Conference on Structural Engineering and Construction, Sapporo, Japan, September 11-13, 2013

[25] M. Sahmaran, H. A. Christianto, I. O. Yaman, "The effect of chemical admixtures and mineral additives on the properties of self-compacting mortars", Cement and Concrete Composites, Vol. 28, No. 5, pp. 432440,2006

[26] B. H. Nagaratnam, M. A. Mannan, M. E. Rahman, A. K. Mirasa, A. Richardson, O. Nabinejad, "Strength and micro structural characteristics of palm oil fuel ash and fly ash as binary and ternary blends in selfcompacting concrete", Construction and Building Materials, Vol. 202, pp. 103-120, 2019 